6) O. E Lancaster, “Jet Propulsion Engines" (1959) Princeton Univ. Press.

7). B. Lewis, R. N. Pease, H.S. Taylor, "Combustion Processes" (1956) Princeton Univ. Press.

8) F. R. W. Hunt, “Internal Ballistics" (1951) SAC, Ministry of Supply, London.

9) "Selected Combustion Problems, First AGARD Colloquim" (1954) Butterworth Pub., London.

10) M. Summerfield, et al, Burning mechanism of ammonium perchlorate propellants: preprint ARS 13 th annual meeting (1958).

11) W. H. Andersen, K.W. Bills, R. O. Shultz, et al, “A model describing combustion of solid composite propellants containing ammonium nitrate": Combustion and Flame 3, 301 (1959).

12) R.F. Chaiken, "A thermal layer mechanism of combustion on solid composite propellants": Combustion and Flame 3, 285 (1959)

13) L. Green, "Erosive burning of some composite solid propellants": Jet Propulsion 24, 9 (1954). Mechanism of ignition of composite solid propellants by hot gases.

14) R.F. McAlevy, P.L. Cown, M. Summerfield : Preprint ARS meeting (1960) January.

15) Solid Propellant Rocket Research Conference at Princeton Univ., Jan. 28 (1960) (ARS meeting) に多 くの“燃焼不安定”に関する報文が提出された。たとえば a) T. Angelus, Unstable burning phenomena in double base propellants.

b) E. W. Price, Analysis of results of combustion instability research on solid propellants.

c) R.H. Wall, Resonant burning of solid propellants ; review of causes, cures and effects.

16) S.I. Cheng, "High frequency combustion instability in solid propellant rockets": Jet Propulsion 24, 27, 102 (1954).

17) L. Green, "Some properties of a simplified model of solid propellant burning": Jet Propulsion 28, 236, 483, 769 (1958).

18) R. W. Hart, F. T. McClure, "Acoustic interaction with a burning propellant surface": J. Chem. Phys. 30, No. 6 (1959) or 'J. Appl. Phys. 31, 884 (1960).

19) R. P. Smith, D. F. Sprenger, "Combustion instability in solid propellant rockets": Fourth Symposium on Combustion p. 893 (1953). Williams and Wilkins, Baltimore.

20) K. Hino, M. Yokogawa, Second International Symposium on Rockets and Astronautics, Tokyo (1960) (Japanese Rocket Society) 講演予稿.

（注）“Third (1949), Fourth (1953), Fifth (1955), Sixth (1957) and Seventh (1959) Symposium (International) on Combustion”か 2 年ことに出版され て拈り，また“Jet Propulsion”現在は改名して“ARS Journal (American Rocket Society)” には多くの関 連文献が報告されている。

\title{
結 合剤としての高分子化合物
}

\section{1 緒言}

固体高速推進燃料1)をわれわれは，固体プロペラントと簡単に 呼んでいるが，これには均質型と不均質型との 2 種類があり；前 者の代表的なものにはダブルベースプロペラント（無煙火薬）が あり，後者ではコンポジットプロペラントが知られている。

本稿では主として，このコンポジットプロペラントの製造に用 いられている高分子化合物について，概観を試みたい。

\section{2 コンポジットプロペラント}

高凍推進用の固体燃料としては，第 2 次大戦頃までは，硝化綿 とニトログリセリンを主成分とする均質可塑物状の，いわゆるダ ブルベースプロペラントが主として用いられていた。しかし大戦 後は，新しく開発されたコンポジットプロペラントが注目され， 現在では世界各国とも，この種のプロペラントの性能の向上に努 カを集中している状況である。

コンポジットプロペラントは結晶性の酸化剤と，それによって 然光る燃料成分とが互に粘結し合った不均質混合物である。これ はまず酸化剤と液状然料成分とを混合し，この混合サスペンジョ ンを型に注入した後, 然料成分の重合硬化反応によって固化させ

\section{松田 義 朗・田中 穆*}

る，いわゆる注型（キャスチング）成形法によって拈括むね製造 されている。このプロペラントはダブルベースプロペラントK比 較して注型成形法により, 種々の形状, サイズのものを容易に製 造し得ること，また製造されたプロペラントの然焼特性が圧力や 温度によって影響を受け難いこと等の長所を有しているため，固 体プロペラントの中で重要な地位を占めるに至っている。

コンポジットプロペラントに执いて，酸化剤の選択については 余り自由がなく，現在工業的に製造されている過塩素酸扣よび硝 酸のアンモニウムまたはカリウム塩が主として使われる。

一方然料成分に関しては, 非常に広範な合成樹脂モノマー、ゴ ム，扣よびプラスチックス類が入手でき，したがって新しい高分 子結合剤の合成において, その構成成分に安い市販素材を利用す ることが可能である。このことから考えると, いろいろの程度の 物理的, 機栈的性質を持った多数のプロペラント組成物の得られ る可能性があるわけである。その意味で，最近のコンポジットプ ロペラントの発展を支えているものは, 近年著しい発達を遂げつ つある高分子化学工業であるといっても過言ではない。

\section{3 コンポジットプロペラントの製造}

話の順序として, 簡単にプロペラントの製造法を説明しよう。 $3 \cdot 1$ プロペラントの設計 
通常プロペラントを製造するに当っては，仕様諸元として， （イ）推力，（口）燃焼時間または燃焼速度，（八）燃婑室圧およ び（二）プロペラントの重量または寸法等が与兄られる。そこで このような仕様諸元の解析を行ない，いかなる組成の, いかなる 形状のプロペラントを製造するがついて方針を決定する必要が ある。この操作を，われわれは “プロペラントの設計” と呼んで いる。

ある特定の寸法の燃䡒室に，ある燃焼速度のプロペラントを収 容する際, その推力および然烧時間は，プロペラントの界面の燃 焼面積を变えることによって調節することができる。燃焼時間が 短くて大きな推力を要求される場合には，燃焼面積を大きくする 必要があり，“内面燃焼方式”が採用され，逆炏然焼時間が長い 代わりに低い推力で十分な場合には, 相対的に燃焼面積が小さく なるよ5に，極端仙は “端面燃焼方式”が採用される（図 1 ）。
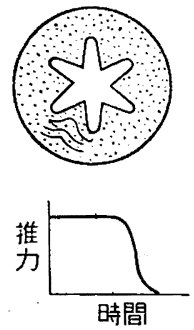
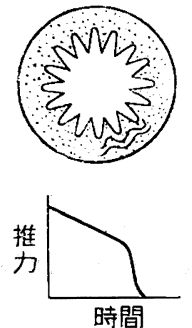
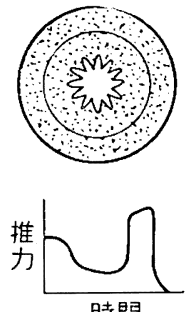

時間
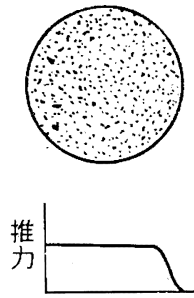

時間
もち論推力括よび然焼速度は, 酸化剂自身の粒度, あるいは酸 化剤と然料成分との組及合せとよる組成の面からも調節すること ができるこの点に関しては，予め種々の材料の組み合わせ処方 そついて十分の基礎データを隼備して扰く必要がある。プロペラ ントの基礎試験は普通 A. R. Deshere 記載)の方法に準拠して行 なわれる。

プロペラント薬体の形状の設計計算法については，幾つかの提 案名が行なわれている。

かくしてプロペラントの製造方針が決定されるわけである。

\section{$3 \cdot 2$ プロペラントの製造}

高速推進然料に打いては，上述のように，それぞれの目的に適 合したエネルギーを発生するに十分な酸化剤を，燃料成分々混合 し成形する必要がある。この場合，通常組成の $70 \%$ 以上を占め る酸化剂の仕込み時の粒子径を，そのまま保ちながら，しかも所 望のサイズおよび形状の薬体に, 安全にから再現性よく成形せ放 ばならないわけでである。

プロペラントの成形法)としては，ゴムやプラスチックスと同

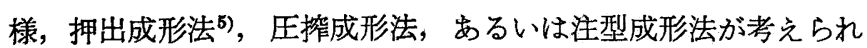
るが, 製品形状の多様性, 危険防止, また品質の均一化等の点か ら，注型成形法が賞用されるところとなっている。注型成形法に よるコンポジットプロペラントの製造工程の概要を図示すると，

因2のと打りである。

操作の細かい点の説明は省略するが，製造工程を通じて重要な 点は, 各操作を十分に検討しプロペラントの性能のばらつきを少 なくするために，品質管理胡が適確に行ない得るよ5に準備され ていなければならないことである。プロペラントの性能の再現 性，信頼性の確立は，製造技術上の重要課題である。

注型法によるプロペラント製造の作業を容易にし，かつ再現性 を得るための一つの要点は, 液状モノマー自身の粘度を適当に調 節するばかりでなく，酸化剂-液状モノマー混合系の粘度をなる

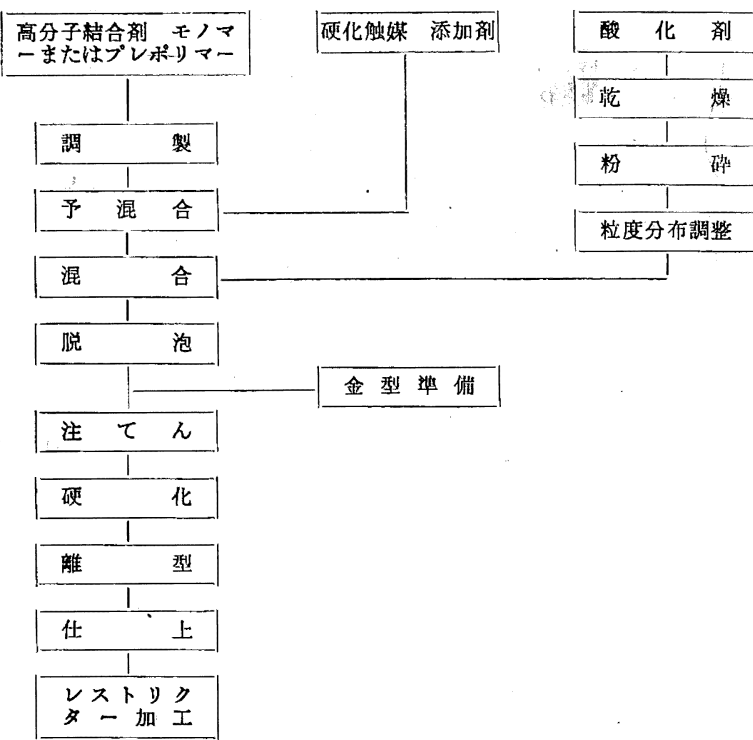

図 2 コンポジットプロペラント の製造工程

ベく低下させることであり，この場合酸化剤の粒度分布の影響が 大きい7。

その他, 複雑な形状の断面を有するプロペラントを成形する場 合には，離型剤の検討が必要であり，またレストリクター加工の ための接着剤の研究も重要な問題である。

\section{$3 \cdot 3$ 検 查}

かくして得られたプロペラントにつき，必要に応じてバッチご とに抜き取り地上燃焼試験を行ない，処方の選定，プロペラント の設計の当否を確かめるとともに，バッチ間のばらつきの有無を 調べて製造工程の管理を行なら。多くのプロペラントは広い温度 範囲 $\left(-50 \sim+70^{\circ} \mathrm{C}\right.$ 程度) で, 燃焼特性に大きな変化のないこ とが裂求されるので，広範な試験が必要とされる。

その他機械的強度，物理的性質の測定を行ならとともに，非破 壊検査を行なら。非破壊検查 ${ }^{8}$ とは，プロペラントの異常燃烧 ま たは爆発の原因となる気泡またはクラック等の欠陷部の存在の有 無につき，X線9または $\gamma$ 線9イ，10)による全数透過圾験を行なら ものである。

\section{4 コンポジットプロペラントの一般的要件}

コンポジットプロペラントの開発に対して一般的に要求される 性能を解析すると，表 1 のと拈りで 表 1 コンポジットプロペ あるが，その主要な点につき簡単に ラントの一般的要件 説明を加えることにしょう。

\section{$4 \cdot 1$ 燃料的特性}

プロペラントの推進性能について の議論は，他の総説にゆずることに して，ここでは簡単な記述に止めて 特く。

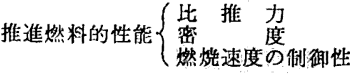

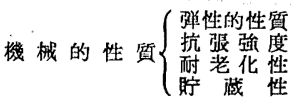

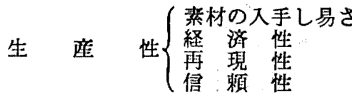

高速推進エンジンも化学的見地から見ると, 一つの化学反応容 器であり, その中で固体プロペラントから加圧ガスへの変化が, 熱力学の法則にしたがって進行するわけである。簡単な熱力学的 計算から比推力を試算 ${ }^{11)} し て$ 見ると，エンジン中の反応関与物質 が化学量論的組成に近ければ，それだけ比推力が高くなることは 容易に理解されるが，いい换えれば，あらゆる化学元素がガス状 
生成物となるまで然焼するためには，燃料をできるだけ多くの酸 化剂と混合すればよいことになる。しかし一方，プロペラント中 の酸化剤の割合を增加すると，それだけ然料成分の量は減るわけ であり，機械的性質の低下は免れないことになる。

\section{$4 \cdot 2$ 機械的強度}

そこで次に㙨械的強度の問題となるが，概してプロペラントは 強度の大きいことが望 まれている。しかしそ の尺度となる数值は余 り明確ではない。

いまプロペラントに つき, 種々の温度に拈 ける典型的な強伸度曲 線を描くと図 $3^{12)}$ のと 扣りである。この場合 この試料は約 $-20^{\circ} \mathrm{F}$ $\left(-30^{\circ} \mathrm{C}\right)$ で粘弾性挙 動から弾性挙動に変化 するが, この変化点, つまり “ぜい化点”で 急激に伸度を低下す る。概して “ぜい化 点”の高いプロペラン トは, ぜい弱であるこ とを意味している。

プロペラントの寒際 の使用条件では, エン ジン内の圧力は相当高くなることが多い。ミリセコンドの間に， 常圧から急激に然烍圧まで圧力が上具する場合，高速度の応力が プロペラントの上に及んでくるのであろう。プロペラントの機械 的性質に及ぼす引張り速度の影響を図 $4^{12}$ ) 亿示す。四からわかる よ5に, 引張り速度が増すとともに, 普通の場合よりも高温側に “ぜい化点”が現われるようになる。したがってプロペラントの 機械的性質を考える場合，なるべく“价化点”の低いものを選 択するのが適当であるといえよう。

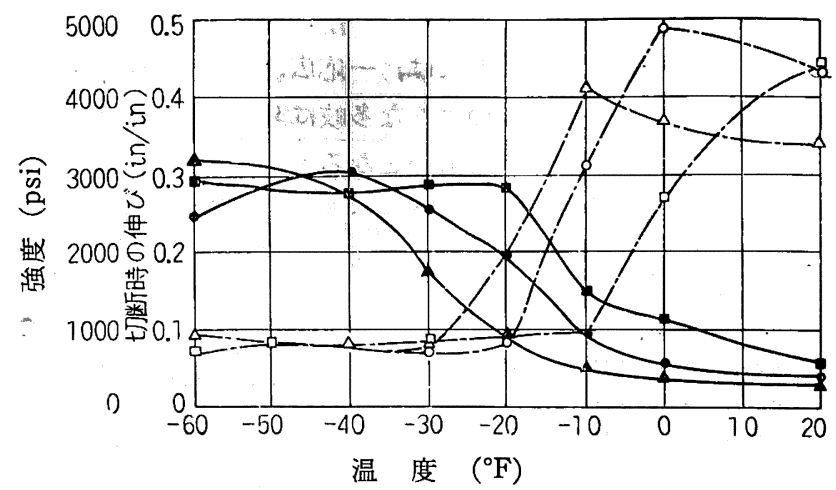

図 4 プロペラントの機㭜的性質に及ぼす引張り速度の影響 仲び - - 强度——A, $\Delta$ 引张り速度 $\times$
- $\bigcirc$ 引㖘り速度 $10 \times$
口, 口㖘り速度 $100 x$

もちろん，機械的強度を引張り強度の面の欢から考えることは 妥当でなく，推進エンジンの発射条件に耐えるためには，プロペ ラントは弾性的な性質を有していることが望まれる。

一般に高分子物質に弾性を保有させるためには，架橋密度を適 度に調節すればよいことは容易に考えられるところであるが，一 方固体プロペシントはその収納される最高温度に拈いて，可塑性 流動に対し十分の抵抗性を有している必要がある。燃烧中にェン ジン内に発生する有効ガス量は，炎にさらされている表面積の関 数であって，プロペラント薬体の形状が，温度によって容易に変 化するものであってはならないわけである。

同様な理由で，貯蔵中にプロペラントが老化，変質，あるいは 寸法, 形状の変化を起さないことが望まれる。

\section{5 結合郕としての高分子化合物の性質}

さてここで，上に述べたような要件を有するコンポジットプロ ペラントに対し, 然料兼結合剤として用いられる高分子化合物 （ポリマー）の性質について，考えて見ることにしよ5。

\section{$5 \cdot 1$ 機 械 的 性 質}

まず機械的性質を考えるに先立ち，ゴムなどに見られる補強剤 的な相互作用の有無を，酸化剂とポリマーとの間について調べて 見よ5。いまプロペラントのクリープの測定から得られた用性率 の逆数，すなわちコンプライアンスを求めて見ると図 $5^{18)}$ のとお りである。酸化剤と然料成分との間になんらの相互作用も存在し ない場合, プロペラントのコンプライアンスは酸化剂ととあに増 大すると考えられるから，図 5 の結果から，一応 2 成分の間には 何らかの相互作用の存在していることが指摘されている。しかし 普通のプロペラント系に括いては，相互作用といっても，補強効 果 ${ }^{14)}$ は認められず，せいぜい2成分の濡れ合いによる容積効果 ${ }^{15)}$ 的な作用しか存在しないと考学るのが妥当のようである。

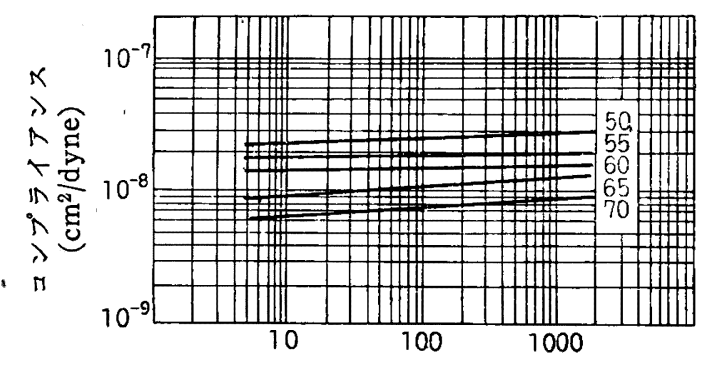

時 間 $(\mathrm{sec})$

因 5 コンポジットプロペラントのクリープ特 性に及ぼす酸化剤濃度の影響

（図中の数字は酸化剂重量 \%)

このように相互作用の弱い組成物では, プロペラントの “ぜい 化温度”とポリマーの 2 次転移温度とほぼ一致するはずであり, その他の機械的性質む，ポリマーの性質と平行関保にあるようで ある。たと竞ば，弾性伸度の大きいポリマーを用いると，プロぺ ラント配合の場合もやはり大きい伸度を示す。

一般に弾性的性質のすぐれた高分子物質は，ゴム状物質，また は弾性体（エラストマー）と呼ばれるが，このよ5な分磧に属す

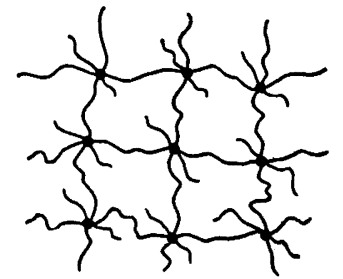

㘡 6 理想的なゴム状弾性 体の分子構造モデル
る物質は，適度に長く，かつ凝集力 の小さい，つまりミクロブラウン運 動を起し易い高分子鎖を骨格とし て，適当の間隔に結び目のある分子 構造を有するすのであるといえる (困6)。

多くの高分子化合物を，その化学 構造の特性に基ついて配列して見る 


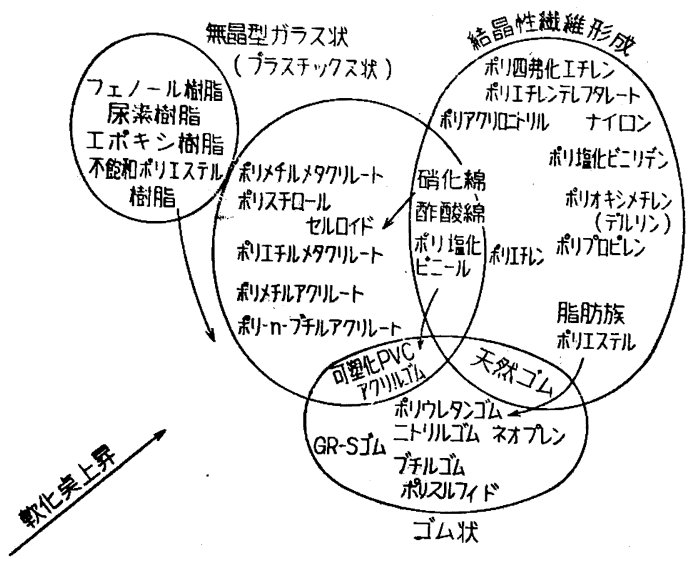

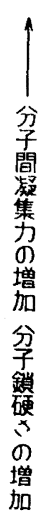

分子化学構造の規則性の增加 結晶度の増加

図 7 高分子物質の分類

と, 図 7 のと拈りであるが ${ }^{17)}$ ，図の下部に位置する高分子を基体 として, これに適当な架橋を施すことが, 高速推進燃料の結合剂 として好適な高分子材料を得る道であると考えられる。

$5 \cdot 2$ 熱化学的性質

プロペラントの場合，高分子物質は結合剂として働くととも に, 然料の役割を要求されるわけであるから，その然焼ェンタル ピーまたは然料としての特性值は非常に重要な因子である。

熱化学的に考えると；初めは弱い結合エネルギーを持ってお り，反応の結果結合エネルギーの大きい，低分子量の燃焼生成物 を生成するような然料成分を用いればよいといらことができる。 つまり炭素が少なく, 水素, 酸素原子を多く含むような化合物が 望ましいが，最近ではニト口基を有する高分子の利用が注目さ れ，アクリル酸ニトロアルキル18)，ニトロポリウレタン19)等が研 究開発されている。また更にホウ素のよ5な軽金属の化合物の固 体プロペラントへの利用も, 将来重要視されるであろ5。

\section{$5 \cdot 3$ 密 度}

よく看過されやすい因子として，然料の密度の問題がある。燃 料を収容する空間が制限される場合, 単位容積当りに生成する工 ネルギーは，単位重量当りのそれより重要な効果を持つはずであ る。したがって密度の高い高分子物質は，それ自身のエンタルピ 一は低いものであっても, 高性能の推進然料を与え得るわけであ る。

\section{4 成形における必要条件}

この点については上述したので省略する。

\section{$5 \cdot 5$ 硬化反応とその必要条件}

先に述べたよ5な注型法によってプロペラントを製造する場 合, 作業条件に適合するような硬化反応様式としては, 液体状の モノマー，またはプレポリマーを用いて加硫，架橋，あるいはグ ラフト重合等の反応によって分子量を增大させ，固体状態に変化 させる方法が一般に採用されている。この場合，もし反応の発熱 が非常に大きいとか，硬化反応を開始させるのに高温を必要とす るならば，高温に拈ける組成物の安定性，および硬化を完了した のち型を冷却する際の, 内部昰生成の可能性をよく注意して扐か ねばならない。Groetzinger ${ }^{20)}$ はプロペラントの硬化反応の進行 に伴な5組成物内の温度分布衿よび重合率の変化の理論計算を試 みたが，その一例を示すと図8のと扣りである。また内部丕の生 成は，硬化反応中の体収縮に起因することが多いので，重合に

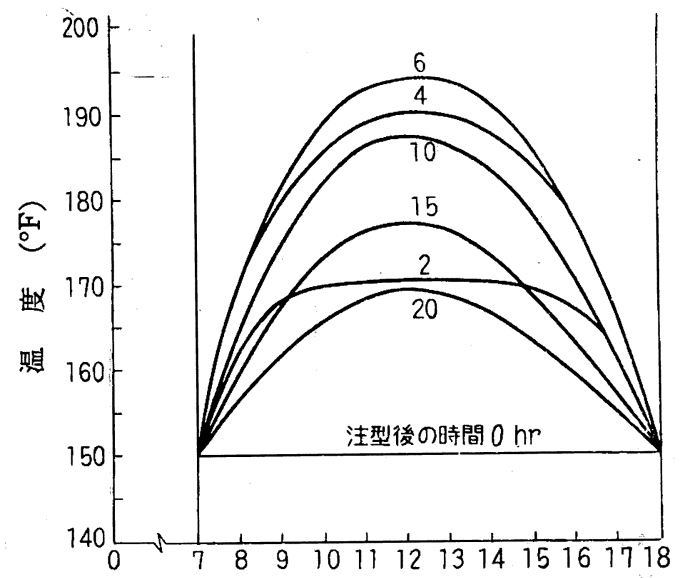

管状薬の中心からの距離（in）

図 8 コンポジットプロペラントの硬化反応における温度分布 より著しく収縮を起すような材料の使用は差しひか竞ねばならな い。

な拉，真空脱泡を行ならためには，原料の揮発性を考慮する必 要があり，また反応の副生物として，プロペラント中に欠陥を生 じさせる傾向のある揮発性物質が生成するようなものは用いられ ない。

\section{6 結合剂としての高分子化合物}

コンポジットプロペラントの結合剤として用いられる高分子化 合物の要件を上に述べたが,これを整理すると次のと扣りである。 燃料としての見地からすれば

（i）水素/炭素の比が大きく，酸素を含有ずる一方，八ロゲ ン, リン，重金属等の元素を含まない分子構造であること。

(ii) 比重の大きいこと。

結合剤としての見地からは,

（i）注型性（重合前は室温で粘度が低く, 蒸気圧の低い液体 で，ポットライフがなるべく長い）を有すること。

（ii）硬化はなるべく低温で円滑に進行し，発熟あるいは収縮 が著しくなく，また酸化剈と反応しないこと。

（iii）硬化重合体は適度の機械的強度, 柔軟性拉よび接着性を 有していること。

等である。

プロペラントの結合剤としては，一応広範な高分子化合物を使 用し得るわけであるが，上のよ5な多岐にわたった要件を，一つ の材料で，すべて兼ね備えたものとなると，その選択は非常に困 難な問題である。コンポジットプロペラントの組成については秘

表 2 結合剂として用いられる高分子化合物 ${ }^{21)}$

\begin{tabular}{|c|c|c|c|c|c|c|c|c|}
\hline 料 & タイプ & 機械性 & 結合性 & 発熟量 & そo & 储考 & 利用度 & 文献 \\
\hline ポリビ ニル化合物 & $\mathrm{TP}$ & 柔 吹 & 良 & 中 & $\begin{array}{l}\text { 内面㜣 } \\
\text { のには }\end{array}$ & 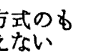 & 中 & 22) \\
\hline アクリル系 & $\mathrm{TP}$ & ぜい弱 & 良 & かなり商 & 同 & 上 & 中 & 22) \\
\hline ポリエチレン & TP & 柔 㳄 & 良 & 高 & 同 & 上 & 中 & 23) \\
\hline セルロース系 & TP & 柔 㳄 & 良 & 非常に高 & 同 & 上 & 高 & 22) \\
\hline ブタジエン系合成ゴム & TS & 柔 欯 & 良 & 低 & & & 高 & \\
\hline 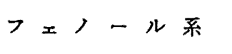 & TS & $\begin{array}{l}\text { ややせ } \\
\text { い弱 }\end{array}$ & 最良 & 中 & & & 低 & 24) \\
\hline エポ キ シ & TS & $\begin{array}{l}\text { ややぜ } \\
\text { い弱 }\end{array}$ & 垠良 & 中 & $\begin{array}{l}\text { ポット } \\
\text { い。高 }\end{array}$ & フが短 & 中 & \\
\hline ポリエステル & TS & $\begin{array}{l}\text { ややぜ } \\
\text { い弱 }\end{array}$ & 最良 & 中 & & & 高 & $\begin{array}{l}25) \\
26)\end{array}$ \\
\hline ポリサルファイド & $\mathrm{TS}$ & 柔 㰞 & 最良 & 高 & $\begin{array}{l}\text { イオウ } \\
\text { 化時間 }\end{array}$ & $\begin{array}{l}\text { 有。硬 } \\
\text { 心. }\end{array}$ & 高 & $\begin{array}{l}27) \\
28)\end{array}$ \\
\hline ポリウレタン & TS & 敡 & 最良 & 离 & $\begin{array}{l}\text { ポット } \\
<\text {, 発 }\end{array}$ & $\begin{array}{l}\text { フブ短 } \\
\text { 易い }\end{array}$ & 高 & $\begin{array}{l}27) \\
28)\end{array}$ \\
\hline
\end{tabular}

TP：熱可塑性, TS : 熟硬化性 
密の分野が多いので，欧米諸国の研究の現状は不明の点が少なく ないが，これまでに多くの高分子結合剤が考えられている。表 2 にその拈もなものを一括して示した。

\section{1 熱可塑性重合物}

多くのビニルまたはアクリル重合物，硝酸緎維素，酢酸緎維 素, あるいはエチル䋐維素系のプラスチックスがこれに属する が，これらは熱軟化性であるため燃䡒中形がくずれやすく，燃焼 速度の温度依存性が大きい欠点があり, 内面然㸁方式(図 1 参照) のものには余り使われない。ただ特殊な例として，ポリ塩化ビニ ルのプラスチゾルが実用されているとの情報 ${ }^{29)}$ がある。

しかし多くのビニルモノマーは㵶維素誘導体や合成ゴムをよく 溶解するし，またジビニル，あるいはジアリルモノマーと共重合 させることによって適当な架橋重合物を生成させることができる ので，このような成分を適当に組み合せて行く方法は検討の余地 がある ${ }^{30)}$ 。たとえばアクリル酸ブチル，アクリル酸ニトロアルキ
ル18)などはその点で注目されるし，アクリル酸アミド31)す利用が 考えられている。

\section{2 熱硬化性重合物}

そこで耐熱性の点から熱硬化性の重合物が注目されるわけであ るが，この系の重合物は硬く，もろくなりすきる欠点があるの で，適当に架橋度を調節することが要点となる。そして実際にま た架橋度の調節によってゴム状弾性体の得られやすいものが，特 に重要視されている。熱硬化性重合物の5ちで, 現在米国で多く 使われているのは, エポキシ, ポリエステル，ポリサルファイド 牤よびポリウレタン等で, 特にポリサルファイドとポリウレタン が激しく優少を競って特り27)，目下のところポリウレタンが，結 合剂として最高のものと考えられている ${ }^{28)}$ 。しかしエポキシ樹脂 やポリエステルも新しい見地から見直せば，必ずしも捨てたるの ではないと考えられる。表 3 に注型可能な熱硬化性結合剂のおる なものを示した。

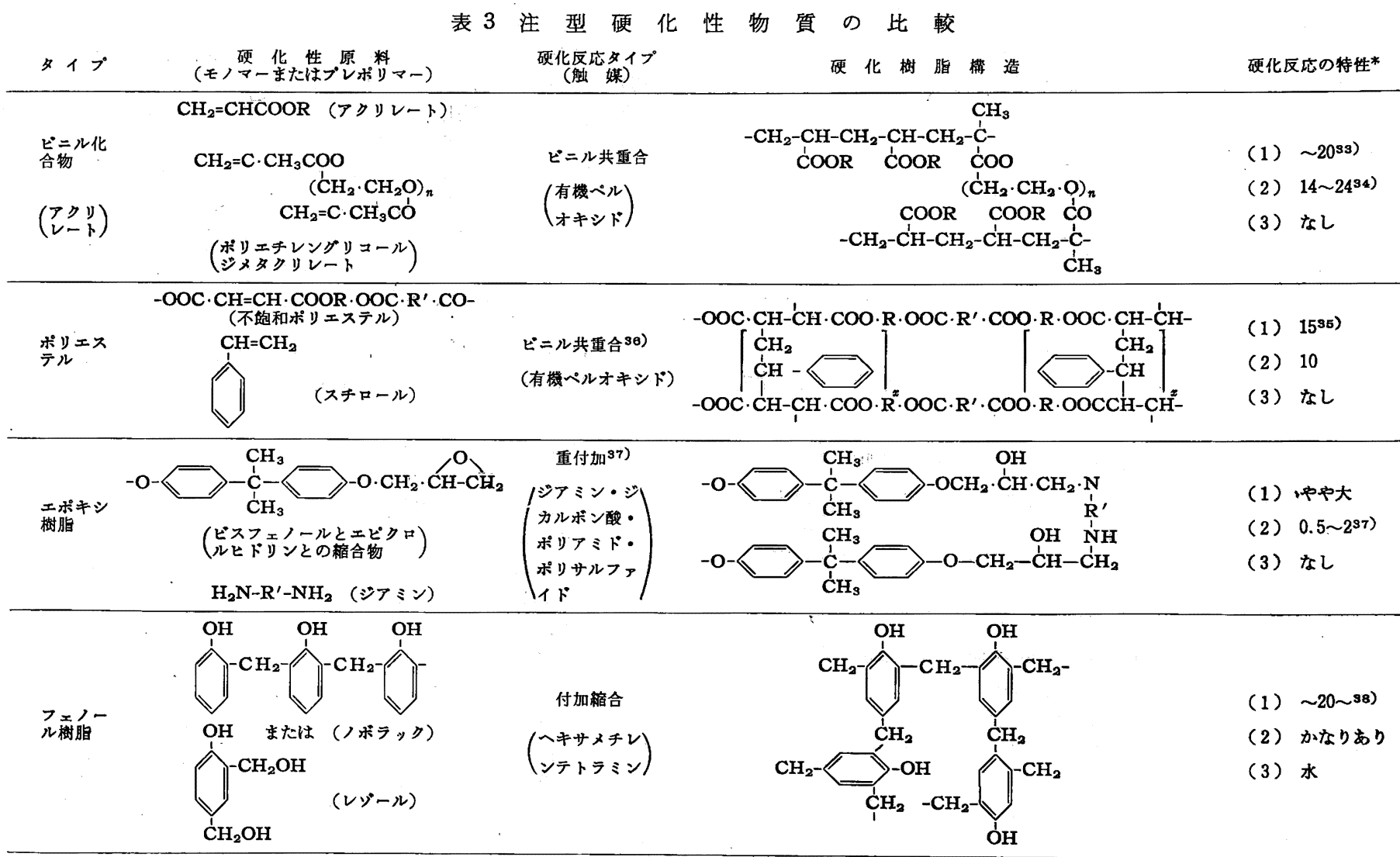

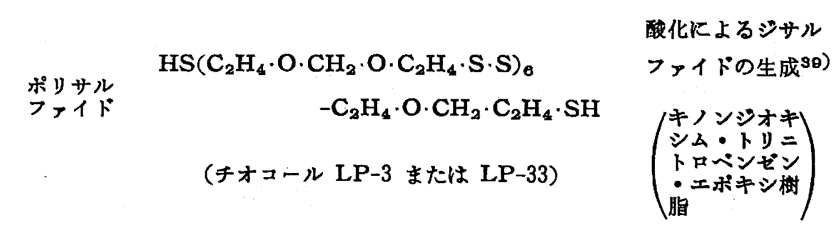

$\mathrm{HO}\left(\mathrm{CH}_{2} \cdot \mathrm{CH} \cdot \mathrm{O}\right)_{n}-\mathrm{H}$ $\mathrm{CH}_{3}$ ポリプロビレングリュール

ポリウレ

重 付 $\mathrm{m}^{40}$ )

トリレンジイソシアネート HO. R.OH

ク゚リニール
$-\mathrm{SS} \cdot \mathrm{C}_{2} \mathrm{H}_{4} \cdot \mathrm{O} \cdot \mathrm{CH}_{2} \cdot \mathrm{O} \cdot \mathrm{C}_{2} \mathrm{H}_{4} \cdot \mathrm{S} \cdot \mathrm{S} \cdot \mathrm{C}_{2} \mathrm{H}_{3} \cdot \mathrm{O} \cdot \mathrm{CH}_{2}$

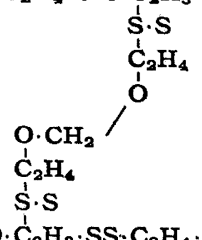

(1) かなり大

(2) $2 \sim 5$

（3）水, アミン

-S.S. $\mathrm{C}_{2} \mathrm{H}_{4} \cdot \mathrm{O} \cdot \mathrm{CH}_{2} \cdot \mathrm{O} \cdot \stackrel{\mathrm{C}}{\mathrm{C}}_{2} \mathrm{H}_{3} \cdot \mathrm{SS} \cdot \mathrm{C}_{2} \mathrm{H}_{4} \cdot \mathrm{O} \cdot \mathrm{CH}_{2}$
（1）此较的小

(2) 比較的小

（3）湿分の存在 Кより $\mathrm{CO}_{2}$ 発生 
その他, 変性尿素樹脂を用いる特許例 ${ }^{32}$ がある。またポリウレ タン結合剂の性能向上のために, ニトロ化ポリウレタンの研究が 行なわれていることは既に述べた。

\section{$6 \cdot 3$ ブタジエン系合成ゴム}

ブタジェン系の合成ゴムとしては種々のものがあるが，概して その加硫は高温を必要とするので, 結合剤として用いるのには問 題がある。しかしエネルギーの低い酸化剤と配合する特殊な場合 には,ブタジェンと 2-メチル-5-ビニルピリジンの共重合物が実 用されている(1)。また別にブタジエンーアクリル酸共重合物の利 用が研究され ${ }^{42)}$, ポリウレタンに匹敵する性能を示すといわれて いる。なおブタジェンの液状重合体の製造は可能49)であるから， この種の液状ゴムの利用も十分考えられてよい。

\section{4 そ の 他}

ホウ素は現在液体然料の面で重要視されているが，固体然料と しての将来性もあり，ボラン（水素化ホウ素）基を固体プロペラ ントへ導入する研究はこれから大い進められるであろう。その 様な目的でポリアセチレンの研究44) 注目されている。その他新 しいニトロ化合物の研究開発45) 引き続いて行なわれるである 5 。

上に述べたところから明らかなように，高分子結合剂の研究に はな持未開拓の分野が多々残されている。飽くことのない性能向 上の要求，多岐にわたる要件に適合させるためには，たえず進歩 しつつある高分子化学の技術を活用しながら，新しく市場に現わ れて来る製品を用い，既存の素材と組み合せて，新規な高分子結 合剂を探求する努力が必要である。

表 4 に典型的なコンポジットプロペラントの組成と，その性能 を例示して扰く。

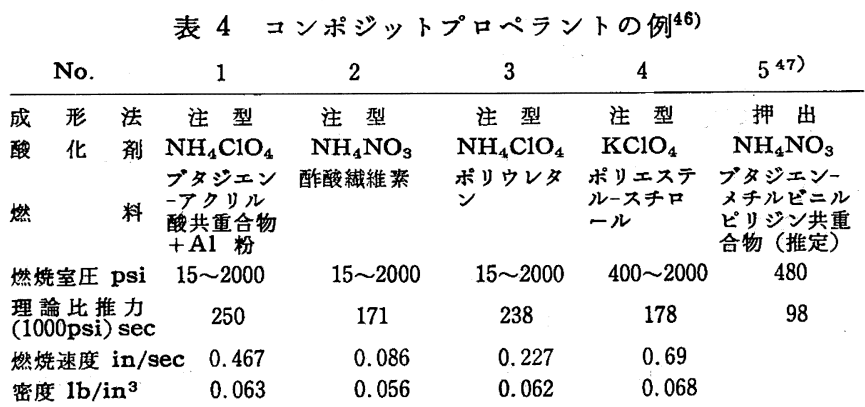

\section{7 結 び}

高速推進然料は，従来のいわゆる燃料や火薬と異なり，新しい 合成化学，高分子化学，あるいはプラスチックスの技術を背景に して，最近急速に進歩を遂げたものである。

かかる進歩の潡しい，そして秘密の多い分野を展望することは なかなか困難な問題であるが，高分子化学の一つの新しい応用分 野を紹介するためあえて一文を草したしだいである。

一文献一

1) (イ) G.P. Sutton, "Rocket Propulsin Elements" (1958).

（口）遠藤, “ロケット工学” (1960).

(八) 正田, 化学と工業 11, 623 (1958).

（二）疋田, 化学の領域 13,788 (1959).

（木）山崎, 有合化協 18, 241 (1960).

2) A. R. Deshere, Ind. Eng. Chem. 49, 1333 (1957).

3) (イ) L.I. Epstein, Jet Propulsion 26, 757 (1956).

(p) M. W. Stone, Jet Propulsion 28, 236 (1958).
（ハ）清水，宇宙科学技術シンポジウム講演 (1960.2.26).

4) J.M. McDermott, Rubber Age 83, 807 (1958).

5) Chem. Eng. 65, 126 (April, 1958).

6) M. Yaffee, Aviation Week 71, 54 (Sept. 7, 1959).

7) K. H. Sweeny, R. D. Geckler, J. Appl. Phys. 25, 1135 (1954).

8) J.F. Hinsley, "Non-Destructive Testing" (1959).

9) (イ) J. Buchanan, B. D. Herbert, Ind. Eng. Chem. 48, 730 (1956).

() Aviation Week 70 (Feb. 17, 1958).

(八) Astronautics 78 (June, 1958).

$(=$ Missiles and Rockts (May 7, 1960).

10) Missiles and Rockets 37 (Mar. 28, 1960).

11) A. O. Dekker, Jet Propulsion 26, 572 (1956).

12) W.F. Arendale, Ind. Eng. Chem, 48, 725 (1956).

13) P. J. Blatz, Ind. Eng. Chem. 48, 727 (1956).

14）（イ）古川，高分子化学 6, 265 (1950).

() F. Buche, J. Polymer Sci. 25, 305 (1957).

(八) G. Kraus, R. L. Collins, India Rubber World 139, 219 (1958).

15）井上，ラバーダイジェスト 12, 2 (No. 3, 1960).

16) 久保, “ゴム弾性”(1947) ほか.

17) (イ) R. Hill, “Fibers from Synthetic Polymers" p. 6 (1953).

() P. Baumann, Chem. and Ind. 1959, 1498.

18）松田，田中，川井ほか，第 2 回ロケットとアストロノーチ ックスに関する国際シンポジウム謴演 (1960.5.25).

19) L. Herzog, M. H. Gold, R. D. Geckler, J. Am. Chem. Soc. 73, 749 (1951).

20) W. H. Groetzinger, ARS Journal 30, 498 (1960).

21) Missiles and Rockets, (April, 1957).

22) F. T. B. Bonell, R. Juhlin, U.S.P. 2, 622, 277 (1952, 12, 23).

23) Missiles and Rockets, 20 (Oct. 26, 1959).

24) C. A. Thomas, B.P. 579, 057 (1947.7.22) および U.S. P. 2,742,672 (1956. 4.24).

25) G. S. Sutherland, D. A. Mahaffy, M. Summerfield, Jet Propulsion 25, 537 (1955).

26) R. L. Hirsch, C.F.Miller, A. Bellin, U. S. P. 2, 780, 996 (1957.2.12).

27) A. J. Zaehringer, Missiles and Rockets, 16(Jan. 12, 1959).

28) J. Holmes, Missiles and Rockets, 24 (Nov. 2, 1959).

29) Chem. Week 48 (Aug. 1, 1959).

30)松田，田中，佐々城ほか，宇宙科学技術シンポジウム譚演 (1960.2.26).

31) M. Scalera, M. Bender, U.S. P. 2, 826, 485(1958. 3. 11).

32) C. A. Thomas, U.S.P. 579, 058 (1946.7.22).

33) E.H. Riddle, "Monomeric Acrylic Esters" (1954).

34) 鶴田, 高分子化学 11，245 (1954).

35) 阿部, 後藤, 高分子化学 12，349 (1955).

36) (イ) B. T. Hayes, W. J. Read, L. H. Vaughan, Chem. and Ind. 1957, 1162.

(ㅁ) H. Hamann, W. Funke, H. Gilch, Angew. Chem. 71, 596 (1959).

37) エポキシ樹脂研究会, “エポキシ樹脂”(高分子文庫).

38）垣内, “高分子化学（化学增刊第 3 号)” (1957), p. 87〜 108.

39) (イ ) E. M. Fettes, J.S. Jorczak, Ind. Eng. Chem. 42, 2217 (1950).

(ㅁ) P.C. Colodny, A. V. Tobolsky, J. Appl. Polymer Sci. 2, 39 (No. 4, 1959).

40) プリヂストンタイヤ K. K. 技術本部ほか, “ポリウレタン” (1960).

41) B. R. Adelman, U.S.P. 2,930,683 (1960,3, 29). 
42) Missiles and Rockets, 24 (May 16, 1960).

43）（イ）伊藤，ラバーダイジェスト 8, 10 (No. 11, 1955) () W.W. Crouch, U.S.P. 2,631, 175 (1953.3.10).

44) Chem. Eng. News 41 (Sept. 28, 1959).

45）難波，第 1 回ロケットとアストロノーチックスに関する国
際シンポジウム講演 (1959.5.25).

46) G. Merrill, “Missile Engineering Handbook-Principles of Guided Missile Design" (1958) p. 292.

47) Astronautics 31 (June, 1958).

\section{原子力航空機と原子力口ケット}

\section{1 は し がき}

周知のよ5にウラン-235 やプルトニウムなどの原子核分裂の 際発生するエネルギーは, 通常の化学反応のエネルギーにくら べ, 単位重量当り約 100 万倍もの大きなものであるから,このエ ネルギーを航空機やロケットの推進用に利用出来れば, 極めて早 い速度で長時間飛行するといった目的には非常に有利になる可能 性がある。ところが，それには幾つかの極めて面倒な問題が解決 されねばならない。

まず第一に，原子核分裂の連鎖反応を，目的に適した一定の速 度で行なわせるように制御せねばならない。ということはェネル ギー発生装置として原子炉を積むことになる。原子炉に呿いて， ウランなどの核然料和よび制御機構などは大して重いものではな い。しかしながら，原子核分裂に伴なら強烈な放射能から乗務員 を保護するためには，この原子炉を厚い密度の高い遮蔽㬝で括括 ラ必要がある。

この遮蔽のための重量が大きいために, 原子力推進は小型の航 空機用には不適当である。

第二に，エンジンの排気の中に放射性物質が混入していたので は，地上にいるものが被害をこうむるので困る。放射性物質の排 出量が極く僅かであれば, 高空を飛行する場合には, 地上に下り るまでに希釈されてしまうのでまず心配ないが，その場合には発 進ならびに高空に達するまでは化学燃料を用いる補助推進機関に よらねばならない。

第三に事故で丞落した場合, 通常の航空機とは比較にならぬ大 きな被害を生ずる可能性がある。原子灯の本質上，墜落のために 原子爆発を起すということは，まずないであろらが，航空機が大 地に激突し破壊された場合, 大量の放射性物質が広範囲に散布さ れる危険がある。高空から落下して，な挆破壊されず放射性物質 を絶対に外に出さね汪と堅牢な原子炬を建造することは容易では なから5。

原子力の利用のらち，この分野が発電や船船推進用にくらべて 遅れているのは, 以上のような難問題を伴なっていることにもよ るが，原子炉の技術からも二つの大きな問題を控兄ている。

第一の技術的困難は，発電用などにくらべ，原子炉の作業温度 の相当に高いことが要求される。現在運転中の多くの発電用原子 炉では運転中の炉内の最高温度部分たる燃料体表面において 500 ${ }^{\circ} \mathrm{C}$ 前後であり, これを $700 \sim 800^{\circ} \mathrm{C}$ に上げるためにあらゆる努力

* 東京大学工学部原子力工学教室. 応用化学教室: 東京都文京区
向坊 隆*

がなされているが容易ではない。これに対し航空機ないしロケッ

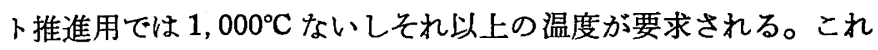
は然料体自身にとっても, 炉の構造材料の面からも極めて面倒な 問題なのである。

第二の技術的問題は, 原子炉のエネルギー発生の速度, 換言す れば核然料の燃烊速度が，高速推進用の場合には発電炉などより 遙かに高いことが要求される。このためには, 原子炉を安全に制 御するといら点で, 現在の発電炉より遙かに高い技術を開発する 必要がある。

これらの困難にもかかわらず，米ソ等の原子力の先進国では, 既に相当な力をこの方面の開発に注ぎ，あらゆる方面から実験が 進められているのは, 高空を高速で長洔間飛行しうる推進機関と して既にある程度の見透しを得ていることを示するのであろう。

\section{2 米ソにおける航空機推進用原子妒開発の概観}

ソ連については後述するように, 最近極く概略が解説的に発表 されたに止まるが，米国に扣ける開発状況についてはかなりの程 度に公表されているので，その慗要を述べることにする1。なお， その他の諸国については発表が見当らないが，莫大な経費を要す る問題でもあり，未だあまり手をつけられていないのであろ5。

米国においては, 原子兵器の製造以外のほとんどあらゆる原子 力に関する事業は 1946 年設立せられた原子力委員会 (AEC)に よって統轄されている。

航空用原子カェンジンの開発もその例にもれず, 軍における研 究もAEC と共同で行なわれているのであるが，米陸軍では1946 年 AEC 設立前既に Fairchild Engine and Airplane 社との契 約の形で研究を開始している。次いで米国海軍ならびに AEC が 研究に加わり, 1951 年には AEC から, 原子核推進による飛行 の理論的検討の結果, 実現の可能性は確実になった旨が公表さ れ，1958 年に原子力航空機の第一機をとばせるとの目標が設定 された。この頃までの実験的研究は, 軽い遮蔽材料とか, 耐熱材 料の研究に限定されていたようで, しかも研究の内容は全く発表 されなかった。

その後, 航空機エンジンで有名な Pratt and Whittney とか, G.E. とかが加わり，研究は次第に盛んになったが，同時に前に 述べたよ5な困難な点も明らかになって来て，1953 年米政府は 開発計画を全面的に改め, 1958 年に第一機をとばす目標は一応 廃棄されて基礎研究をすすめることになった旨が発表された。

1956 年には米空軍が爆撃機 B-36 に原子炬を搭載して飛行寒 